\title{
ALEXANDRIUM TAMUTUM SP. NOV. (DINOPHYCEAE): A NEW NONTOXIC SPECIES IN THE GENUS ALEXANDRIUM ${ }^{1}$
}

\author{
Marina Montresor ${ }^{2}$ \\ Stazione Zoologica 'A. Dohrn,' Villa Comunale, 80121 Naples, Italy \\ Uwe John
}

Alfred Wegener Institute for Polar and Marine Research, Am Handelshafen 12, 27570 Bremerhaven, Germany

Alfred Beran

Laboratorio di Biologia Marina, Via Auguste Piccard 54, 34010 Trieste, Italy

and

Linda K. Medlin

Alfred Wegener Institute for Polar and Marine Research, Am Handelshafen 12, 27570 Bremerhaven, Germany

A new species of the dinoflagellate genus Alexandrium, A. tamutum sp. nov., is described based on the results of morphological and phylogenetic studies carried out on strains isolated from two sites in the Mediterranean Sea: the Gulf of Trieste (northern Adriatic Sea) and the Gulf of Naples (central Tyrrhenian Sea). Vegetative cells were examined in LM and SEM, and resting cysts were obtained by crossing strains of opposite mating type. Alexandrium tamutum is a small-sized species, resembling $A$. minutum in its small size, the rounded-elliptical shape and the morphology of its cyst. The main diagnostic character of the new species is a relatively wide and large sixth precingular plate $\left(6^{\prime \prime}\right)$, whereas that of $A$. minutum is much narrower and smaller. Contrary to $A$. minutum, A. tamutum strains did not produce paralytic shellfish poisoning toxins. Phylogenies inferred from the nuclear small subunit rDNA and the D1/D2 domains of the large subunit nuclear rDNA of five strains of $A$. tamutum and numerous strains of other Alexandrium species showed that $A$. tamutum strains clustered in a well-supported clade, distinct from $A$. minutum.

Key index words: Alexandrium; Alexandrium minutum; Alexandrium tamarense; Alexandrium tamutum sp. nov.; LSU rDNA; Mediterranean Sea; phylogeny; SSU rDNA, taxonomy

Abbreviations: GTX, gonyatoxins; HAB, harmful algal bloom; L:D, light:dark; LSU, large subunit; ML, maximum likelihood; MP, maximum parsimony; NJ, neighbor joining; PSP, paralytic shellfish poisoning; psu, practical salinity units

\footnotetext{
${ }^{1}$ Received 18 March 2003. Accepted 25 December 2003.

${ }^{2}$ Author for correspondence: e-mail mmontr@szn.it.
}

An apparent increase in the frequency and intensity of harmful algal blooms (HABs) has fostered research aimed at understanding the taxonomy, ecology, and distribution of the microalgae involved. $\mathrm{HAB}$-forming species often produce potent toxins that can cause serious to fatal illnesses to humans and other vertebrates (Ochoa et al. 1997, Codd et al. 1999, Scholin et al. 2000) and create serious financial losses to local aquacultural activities (Hoagland et al. 2002). Therefore, monitoring programs have been established in many coastal regions, especially those with important mariculture and fishing industries. Proper insight in the taxonomic diversity of $\mathrm{HAB}$-forming species and in their characteristics constitutes a crucial prerequisite to the success of these monitoring programs. Recent studies have revealed that genera with $\mathrm{HAB}$-forming algae are generally far more diverse and more widely distributed than originally believed.

The microalgal genus Alexandrium (Dinophyceae, Gonyaulacales) includes 28 described species (Balech 1995, MacKenzie and Todd 2002), eight of which are known to produce paralytic shellfish poisoning (PSP) toxins (Moestrup et al. 2002). PSP events were not an issue for the Mediterranean Sea until about 10 years ago, when the first toxic outbreak attributed to Alexandrium minutum was reported for the Spanish Mediterranean coast (Delgado et al. 1990). Alexandrium minutum, the type species of the genus, was described from the harbor of Alexandria (Egypt), where it caused intense blooms (Halim 1960). This species has been repeatedly recorded during the last decade in Mediterranean waters, and blooms have been related with PSP toxin production along the Spanish and French coasts and in the Adriatic Sea (Vila et al. 2001a). Two other toxic Alexandrium species known from the Mediterranean Sea are A. andersoni and A. catenella. The first species has been recorded as encysted stage in the Gulf of Naples (Montresor et al. 1998), and PSP 
toxins were found in cultures obtained from cyst germination (Ciminiello et al. 2000), but there have been no reports of PSP events attributable to $A$. andersoni yet. In Europe, chain-forming $A$. catenella was first recorded offshore the coast of Spain in 1983 (Margalef and Estrada 1987), and a number of PSP events along the Spanish and French coasts have been associated with this species in the last years (Vila et al. 2001a,b, Lilly et al. 2002). Alexandrium tamarense is responsible for PSP events worldwide and has been recorded along the Spanish, French, and Italian coasts, but there is no evidence of toxic events related to this species along the Mediterranean coasts (Vila et al. 2001a).

Identification and quantification of Alexandrium species are difficult when cells are observed in LM. Several species share a similar cell outline and size range. They can be distinguished only by small morphological details of their thecal plates (Balech 1995) made visible in LM upon staining plates with fluorochromes (Fritz and Triemer 1985), after dissecting them under the microscope, or by examination with SEM. Molecular approaches have been used to unravel phylogenetic relationships among the different species of the genus Alexandrium (Scholin et al. 1993, Adachi et al. 1994), to trace dispersal patterns of toxic Alexandrium species (Anderson et al. 1994, Scholin et al. 1995, Medlin et al. 1998, Lilly et al. 2002), and to infer the biogeographic history of the genus (John et al. 2003b). The detection of species- or strainspecific molecular markers has been widely explored in the last years to gain alternative and precise tools that facilitate the identification of this problematic group of species (Scholin et al. 1994, Adachi et al. 1996a,b, Scholin and Anderson 1996, Anderson et al. 1999, Penna and Magnani 2000, John et al. 2003a).

In the frame of long-term phytoplankton monitoring projects carried out in the Gulf of Trieste (northern Adriatic Sea, Mediterranean Sea) and in the Gulf of Naples (central Tyrrhenian Sea, Mediterranean Sea), a new species of the genus Alexandrium, A. tamutum sp. nov., has been recorded. We present the results of morphological studies based on culture material by LM and SEM and of the molecular phylogenetic analyses carried out on the small subunit (SSU) and the D1 and D2 domains of the large subunit (LSU) of the nuclear rDNA.

\section{MATERIALS AND METHODS}

Cultures. The cultures used for morphological and molecular analysis are listed in Table 1. Morphological investigations were carried out on A. tamutum strains isolated from net phytoplankton samples collected in surface waters of the Gulf of Naples (Tyrrhenian Sea) on 18 May 2000 (strains SZN28 and SZN29, maintained in the culture collection of Stazione Zoologica 'A. Dohrn') and in the Gulf of Trieste (Adriatic Sea) on 14 January and 12 March 1997 (strains A8/1, A3 T, and AT5). Two strains of $A$. minutum were also studied: SZN30 isolated from the Gulf of Naples on 18 May 2000 and L20/2 isolated from the Gulf of Trieste on 17 March 1998. Cultures were established by the isolation of a single cell from net phytoplankton samples. Cultures were grown in glass tubes filled with $30 \mathrm{~mL}$ of $\mathrm{K}$ medium (Keller et al. 1987) prepared with oligotrophic seawater adjusted to a salinity of $36 \mathrm{psu}$ by the addition of double distilled water. Tubes were kept at a temperature of $20^{\circ} \mathrm{C}$, a photon flux density of $100 \mu \mathrm{mol}$ photons $\cdot \mathrm{m}^{-2} \cdot \mathrm{s}^{-1}$, and a 12:12-h light:dark (L:D) photocycle.

For DNA extraction, unialgal strains of $A$. minutum and $A$. tamutum were grown in 1-L Erlenmeyer flasks in IMR/2 growth medium (Eppley et al. 1967), supplemented with $10 \mathrm{nM}$ selenite, or in $\mathrm{K}$ medium in the case of $A$. affine. All cultures were maintained at $15^{\circ} \mathrm{C}$ in a controlled growth chamber with a 14:10-h L:D photocycle at a photon flux density of $150 \mu \mathrm{mol}$ photons $\cdot \mathrm{m}^{-2} \cdot \mathrm{s}^{-1}$.

Morphological observations. Exponentially growing cells were fixed with formaldehyde $(0.6 \%$ final concentration) and examined and photographed with a Zeiss Axiophot microscope (Carl Zeiss, Oberkochen, Germany) equipped with an AxioCam (Carl Zeiss) photocamera. For plate pattern identification, cells were stained with calcofluor white (Fritz and Triemer 1985) and observed with the same microscope equipped with a UV mercury lamp and a Zeiss 487701 filter set.

For SEM examination, exponentially growing cultures were fixed with formaldehyde (final concentration of $1.6 \%$ ), dehydrated in a graded ethanol series, critical point dried, and sputter coated with gold. The material was examined with a scanning electron microscope (model 505, Philips Electron Optics BV, Eindhoven, The Netherlands). For plate designation, the notation proposed by Balech (1995) was used.

Cyst production. Cyst production in A. tamutum was tested by crossing strains SZN28 and SZN29 (Gulf of Naples) and strains AT3, AT5, and A8/1 (Gulf of Trieste). All strains were inoculated individually and in all pair-wise combinations (to a final concentration of 500 cells $\cdot \mathrm{mL}^{-1}$ ) in single wells of tissue culture plates filled with $8 \mathrm{~mL}$ of diluted $\mathrm{K}$ medium $(\mathrm{K} / 25)$. Plates were incubated at a temperature of $20^{\circ} \mathrm{C}$, a photon flux density of $50 \mu \mathrm{mol}$ photons $\cdot \mathrm{m}^{-2} \cdot \mathrm{s}^{-1}$ provided by coolwhite fluorescent bulbs, and a 12:12-h L:D photocycle. Plates were periodically inspected for 6 weeks with LM for cyst production.

Toxin analysis. All cultures of $A$. tamutum and the $A$. minutum strain SZN30 from the Gulf of Naples were tested for PSP toxin production. Cultures were grown in $500-\mathrm{mL}$ Erlenmeyer flasks filled with $250 \mathrm{~mL}$ of K culture medium at the same temperature and light conditions used for culture maintenance. Cultures in exponential growth phase were centrifuged and the pellet resuspended in $0.05 \mathrm{M}$ acetic acid. HPLC analyses for saxitoxin, neosaxitoxin, and gonyatoxins (GTX) were carried out following the method of Sullivan and Wekell (1984).

DNA extraction, amplification of $r D N A$ genes, and sequencing. DNA extractions were made from $1 \mathrm{~L}$ of culture in logarithmic growth phase, which were harvested with filtration through a 3- $\mu \mathrm{m}$ Isopore membrane filter (Millipore, Schwalbach, Germany) and washed once with sterile seawater. Cells were washed from the filters with $3 \mathrm{~mL}$ preheated $\left(65^{\circ} \mathrm{C}\right) 3 \%$ hexadecyltrimethylammonium bromide into 15 $\mathrm{mL}$ reaction tubes (Sarstedt, Nünbrecht, Germany), and DNA was extracted following the procedure of Doyle and Doyle (1990). Thereafter the DNA was treated with $10 \mu \mathrm{L}$ RNase A (10 mg $\left.\cdot \mathrm{mL}^{-1}\right)$ (Qiagen, Hilden, Germany) for a 30min incubated at room temperature, followed by a 90 -min incubation in a thermoshaker at $37^{\circ} \mathrm{C}$ with $20 \mu \mathrm{L}$ of proteinase $\mathrm{K}\left(10 \mathrm{mg} \cdot \mathrm{mL}^{-1}\right)$, and purified using phenol:chloroform extraction with alcohol precipitation. DNA concentration was measured spectrophotometrically at $260 \mathrm{~nm}$, and integrity was verified by agarose-gel electrophoresis. SSU PCR amplification was done with approximately $100 \mathrm{ng}$ DNA in a mix of $86.5 \mu \mathrm{L}$ water/DNA, $10 \mu \mathrm{L} 10 \times$ Taq DNA 


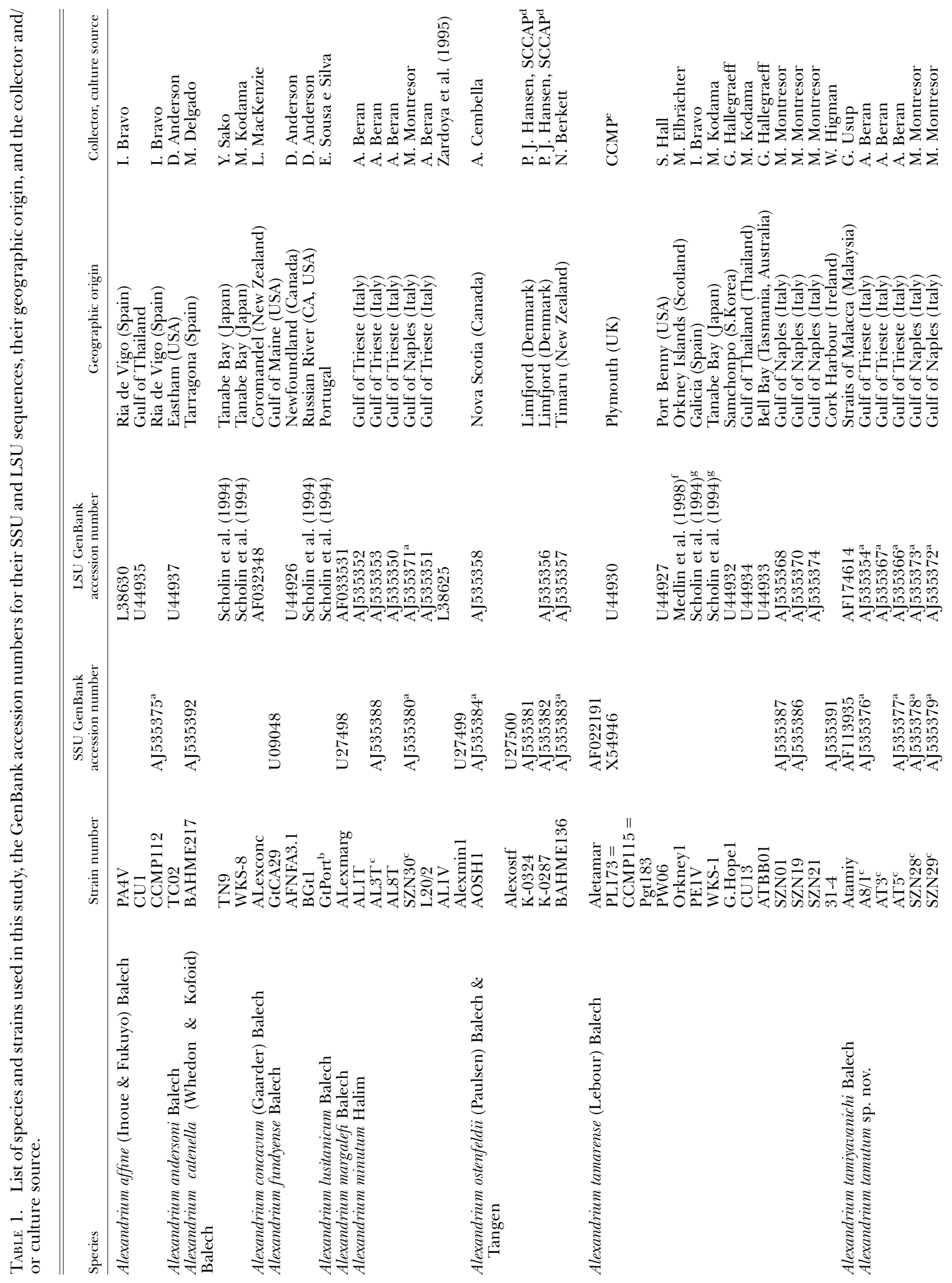




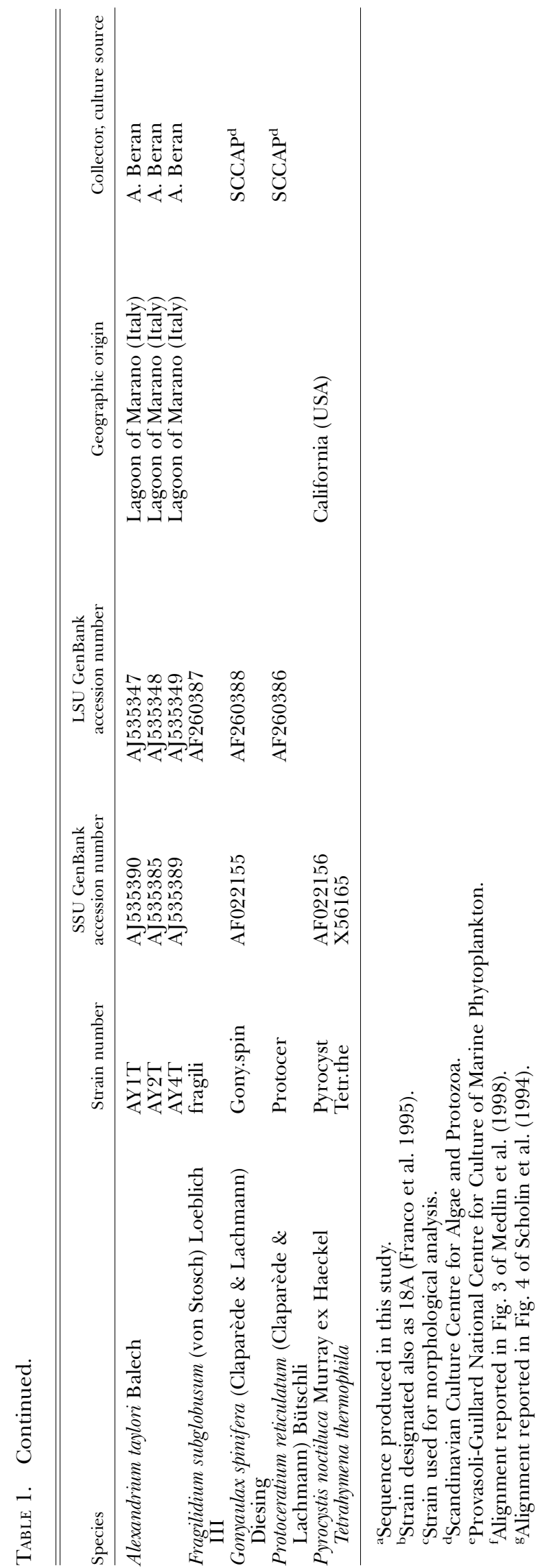

polymerase buffer (Perkin Elmer-Applied Biosystems, Weiterstadt, Germany), $1 \mu \mathrm{L} 1 \mathrm{~F}$ primer $\left(5^{\prime}\right.$-aac ctg gtt gat cct gcc agt-3'; $10 \mathrm{pmol} \cdot \mu \mathrm{L}^{-1}$ ), $1 \mu \mathrm{L} 1528 \mathrm{R}$ primer (5-tga tcc ttc tgc agg ttc acc tac- $\left.3^{\prime} ; 10 \mathrm{pmol} \mu \cdot \mathrm{L}^{-1}\right), 1 \mu \mathrm{L} 10 \mathrm{mM}$ dNTPs (Amersham Pharmacia Biotech, Freiburg, Germany), and $0.5 \cdot \mu \mathrm{L}$ Taq DNA polymerase $\left(5 \mathrm{U} \cdot \mu \mathrm{L}^{-1}\right.$, Perkin ElmerApplied Biosystems). These are the same primers as in Medlin et al. (1988) but without the restriction sites.

The D1/D2 region of the LSU rDNA was amplified using the same PCR reaction mix as described above but using the DIRF primer $\left(5^{\prime}\right.$-acc cgc tga att taa gca ta- $\left.3^{\prime}\right)$ and D2CR primer $\left(5^{\prime}\right.$-cct tgg tcc gtg ttt caa ga-3'), according to Scholin et al. (1994). The PCR reaction was carried out in a Mastercycler Gradient (Eppendorf, Hamburg, Germany) with an initial denaturation of $94^{\circ} \mathrm{C}$ for $4 \mathrm{~min}$ followed with 30 cycles of $94^{\circ} \mathrm{C}$ for $2 \mathrm{~min}$ (denaturation), $56^{\circ} \mathrm{C}$ for $2 \mathrm{~min}$ (annealing), and $72^{\circ} \mathrm{C}$ for $2 \mathrm{~min}$ (extension). PCR reactions were carried out in triplicate. The triplicates were pooled, purified with Qiagen PCR purification kit, and then sequenced using the Long Read kit (Biozym, Hessisch Oldendorf, Germany) on a LiCor 4000L automatic sequencer (MWG, Ebersberg, Germany), according to the manufactures instructions. For the SSU rDNA sequencing reaction, we used the following primers, which were optimized for use on a LiCor sequencer with a $5^{\prime}$ IRD 800 modification. These are slightly different (longer/shifted) than the original versions published in Elwood et al. (1985): $1 \mathrm{~F}$ primer $\left(5^{\prime}\right.$-aac ctg gtt gat cct gcc agt- $\left.3^{\prime}\right), 528 \mathrm{~F}\left(5^{\prime}\right.$-gcg gta att cca gct cca a- $\left.3^{\prime}\right), 1055 \mathrm{~F}\left(5^{\prime}\right.$-ggt ggt gca tgg ccg ttc tt- $\left.3^{\prime}\right), 536 \mathrm{R}\left(5^{\prime}\right.$-aat tac cgc ggc kgc tgg ca- $\left.3^{\prime}\right), 1055 \mathrm{R}\left(5^{\prime}\right.$-acg gcc atg cac cac cac cca t$\left.3^{\prime}\right), 1528 \mathrm{R}\left(5^{\prime}\right.$-tga tcc ttc tgc agg ttc acc tac- $\left.3^{\prime}\right)$. For D1/D2 region of the LSU, we used the DIRF primer $\left(5^{\prime}\right.$-acc cgc tga att taa gca ta- $\left.3^{\prime}\right)$ and $739 \mathrm{R}\left(5^{\prime}\right.$-ggt ccg tgt ttc aag acg gg- $\left.3^{\prime}\right)$.

Phylogenetic analyses. Sequence alignment was done with Clustal $\times$ software (Thompson et al. 1997) and improved by eye for both the SSU sequence and the LSU sequence. Alignments are available at GenBank or have been published in the literature (Table 1). For the SSU rDNA we used a data set containing 28 taxa and 1751 bp with Tetrahymena thermophila, Gonyaulax spinfera, and Pyrocystis noctiluca as outgroup species. An optimal base substitution model was calculated using Modeltest (Posada and Crandall 1998, 2001). Maximum likelihood (ML) analyses were constrained with the optimal parameters as obtained by hierarchical likelihood ratio tests (hLRTs). ML phylogenies were reconstructed with PAUP* 4.0b8 (Swofford 1998) constrained with the following Modeltest parameters. hLRTs gave a general time reversible (GTR) model, allowing for invariant sites and a gamma distribution $($ GTR $+\mathrm{I}+\mathrm{G})$ as the model that fit best the data set. The ML-tree calculation was constrained using base frequencies of $\mathrm{A}=0.27665, \mathrm{C}=0.1779, \mathrm{G}=0.2547$, $\mathrm{T}=0.2908$; base substitution frequencies of $\mathrm{A}-\mathrm{C}=0.9683$, $\mathrm{A}-\mathrm{G}=2.6044, \quad \mathrm{~A}-\mathrm{T}=1.1677, \quad \mathrm{C}-\mathrm{G}=0.6080, \quad \mathrm{C}-\mathrm{T}=5.2852$, $\mathrm{G}-\mathrm{T}=1.0000$; proportion of invariable sites $\mathrm{I}=0.2652$; and a gamma distribution shape parameter $=0.6411$.

The data set for the D1/D2 region of the LSU rDNA contained 42 taxa and 635 unambiguous nucleotide positions. The tree was rooted using Fragilidium subglobosum, Protoceratium reticulatum, and $G$. spinifera as multiple outgroups. ML phylogenies were reconstructed with PAUP* 4.0b8 (Swofford 1998). The selected model, using hLRTs for the partial LSU rDNA data set, was the GTR model with a gamma distribution $(\mathrm{GTR}+\mathrm{G})$; base frequencies of $\mathrm{A}=0.2657, \mathrm{C}=0.1647$, $\mathrm{G}=0.2482, \mathrm{~T}=0.3214$; base substitution frequencies of $\mathrm{A}-$ $\mathrm{C}=0.6874, \quad \mathrm{~A}-\mathrm{G}=1.7143, \mathrm{~A}-\mathrm{T}=0.7864, \quad \mathrm{C}-\mathrm{G}=0.4543$, C$\mathrm{T}=3.3605, \mathrm{G}-\mathrm{T}=1.0000$; proportion of invariable sites $\mathrm{I}=0$; and gamma distribution shape parameter $=0.7306$.

Nodal support was estimated by bootstrap analyses (Felsenstein 1985) using maximum parsimony (MP), neighbor joining $(\mathrm{NJ})$ with ML distances, and ML analyses with the model 
parameters described above. The bootstrap analyses were done in 1000 replicates for MP and NJ and with 100 replicates for the ML analysis.

\section{RESULTS}

Alexandrium tamutum Montresor, Beran and John sp. nov.

Fig. 1, A-B, Fig. 2, A-C, Fig. 3, A-G, Fig. 4, A-B

Cellulae longae 19-33.7 $\mu \mathrm{m}$ et latae 19-32.6 $\mathrm{m}$, forma rotunda usque ad ellipticam. Cingulum excavatum est et 1/1 sua latitudine sub laeva parte descendit. Formula laminarum:

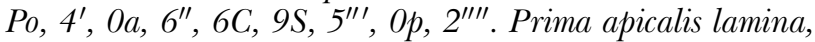
rhombi inaequalis forma, cum lamina Po coniuncta est. Parvum ventrale foramen in anteriore dextero margine primae apicalis laminae adest. Sexta praecingularis lamina $\left(6^{\prime \prime}\right)$ tam lata quam longa est. Sulci posterior lamina (Sp), fere rectianguli forma, magis lata quam longa est. Thecae laminae subtiles et leves sunt cum parvis poris. Rotundae cistes sunt (diameter $=26-32 \mu \mathrm{m})$ cum a summo videntur et renis forma (altitudo $=16-20 \mu \mathrm{m}$ ) cum iuxta videntur. Cistis paries spissus est et corio mucoso circumdatus; id quod cistis continet granosum est et stigma, colore quasi fusco, adest.

Cells 19-33.7 $\mu \mathrm{m}$ long and 19-32.6 $\mu \mathrm{m}$ wide, round to elliptical in shape. Cingulum excavated with its right end displaced posteriorly one cingular width. Plate pattern: Po, 4', 0a, 6" , 6C, 9S, 5"', 0p, $2^{\prime \prime \prime \prime}$. The first apical plate is irregularly rhomboidal and contacts Po. A small ventral pore is present on the anterior right margin of the first apical plate. The sixth precingular plate $\left(6^{\prime \prime}\right)$ is as wide as long. The posterior sulcal plate (Sp) is roughly rectangular, wider than longer. Thecal plates are thin and smooth, with small pores. Cysts are circular (26-32 $\mu \mathrm{m}$ diameter) when seen from above and kidney shaped (16-20 $\mu \mathrm{m}$ high) when seen from the side. Cyst wall is thick and surrounded by a mucous layer; cyst content is granular and a brownish accumulation body is present.

Habitat: Marine

Type locality: Gulf of Naples, Tyrrhenian Sea, Mediterranean Sea
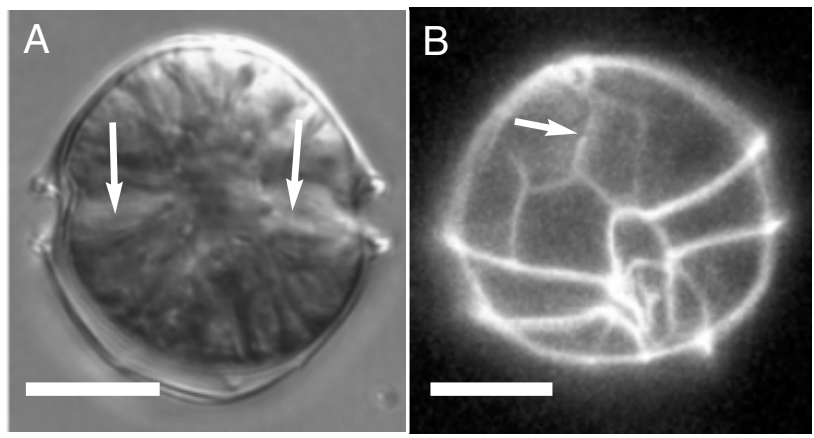

FIG. 1. Alexandrium tamutum sp. nov., light micrographs of vegetative cells. (A) Nomarski optics micrograph of a cell in ventral view (strain SZN28) the two ventral arms of the horseshoe-shaped nucleus are shown by an arrow. (B) Calcofluor-stained cell of strain AT5 in ventral view; the ventral pore is shown by an arrow. Scale bars, $10 \mu \mathrm{m}$.
A

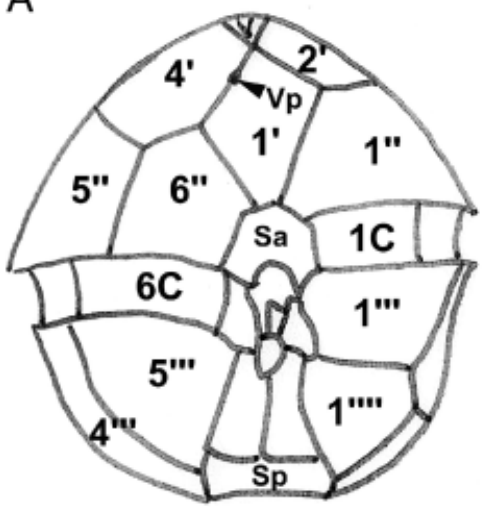

C

B
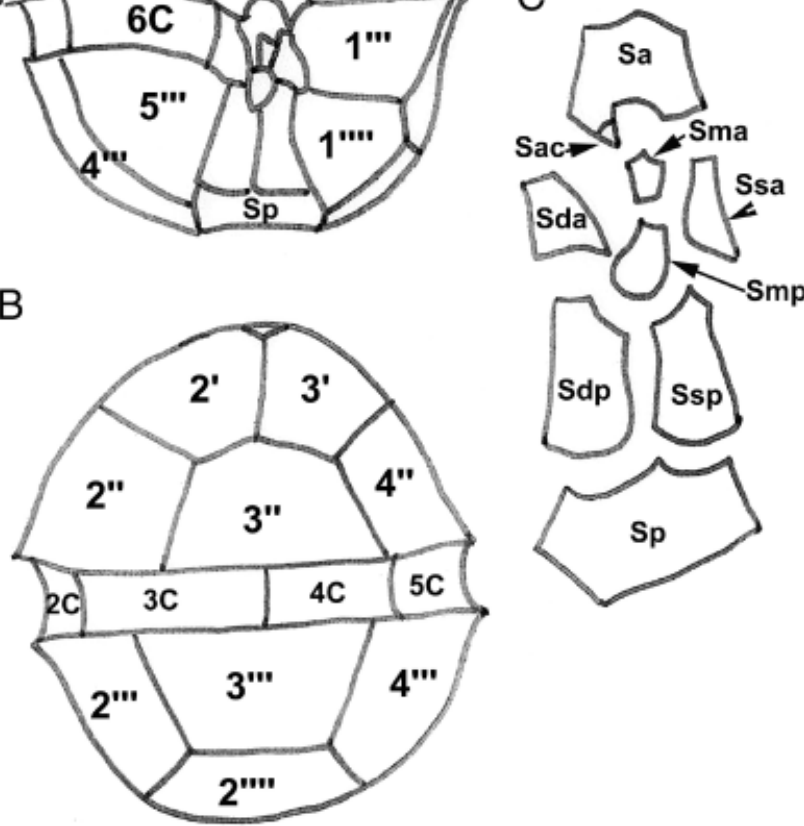

FIG. 2. Alexandrium tamutum sp. nov., schematic drawings of thecal plate patterns. (A) Ventral view, (B) dorsal view, (C) sulcal area. For abbreviations, see Figure 3.

\section{Holotype: Figure $3 \mathrm{~A}$}

Iconotype: Figure 2, A-C

Etymology: The word tamutum is composed by the first part of the word "tamarense" and the last part of the word "minutum" and indicates the morphological

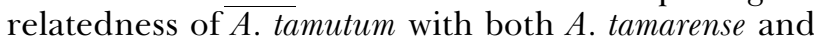
A. minutum.

Cell shape is rounded to elliptical (Figs. 1, 2, A and B, and $3, \mathrm{~A}$ and $\mathrm{B}$ ), but larger cells in ventral view can have a slightly pentagonal outline (Fig. 3A). Cell size ranges from 19 to $33.7 \mu \mathrm{m}$ in length and from 19 to $32.6 \mu \mathrm{m}$ in width (Table 2); cell depth is almost equal to cell width. The epitheca is dome shaped, almost hemispherical in most cells, but it can be helmet shaped in larger cells because of a change in curvature of the epitheca toward the cingulum. The hypotheca is hemispherical to almost trapezoidal when cells are slightly tilted; the antapical margin of the hypotheca in correspondence to the sulcal area is flat and the left portion of the hypotheca is slightly protruding (Fig. 3D). The cingulum is excavated, descending its own width, and is bordered by very narrow cingular lists (Figs. 1B, 2A, and $3, \mathrm{~A}, \mathrm{~B}, \mathrm{D}$, and $\mathrm{E}$ ). The sulcus is slightly depressed, with narrow sulcal lists, the left list wider than the right one (Fig. 3, A and D). When cells are slightly tilted, the 


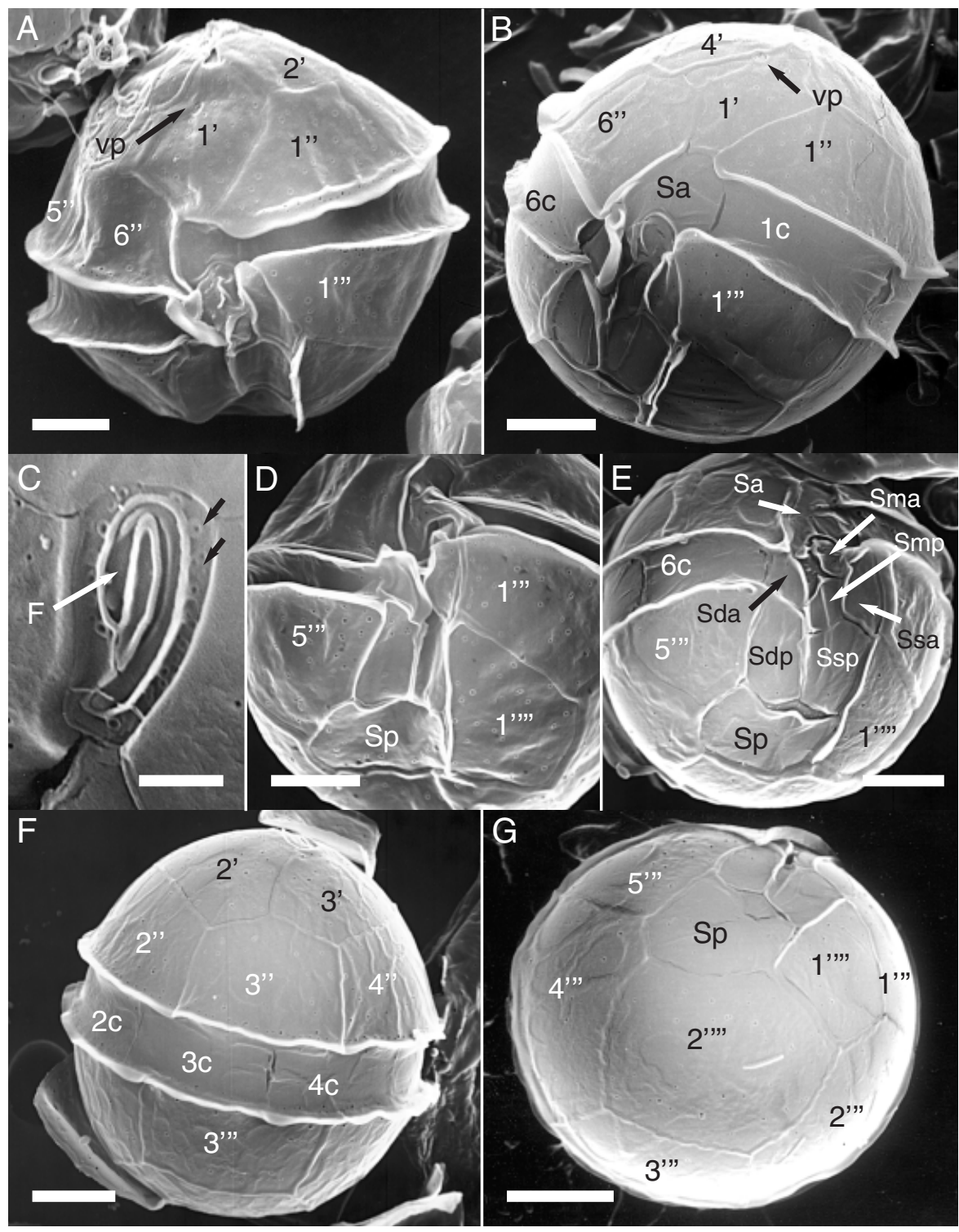

Fig. 3. Alexandrium tamutum sp. nov., SEM micrographs of vegetative cells. $1^{\prime}$ up to $4^{\prime}$, apical plates; vp, ventral pore; $1^{\prime \prime}$ up to $6^{\prime \prime}$, precingular plates; $1 \mathrm{c}$, up to $5 \mathrm{c}$, cingular plates: $\mathrm{Sa}$, sulcal anterior plate; Sma, sulcal median anterior plate; Smp, sulcal median posterior plate; Sda, sulcal right anterior plate; Ssa, sulcal left anterior plate; Sdp, sulcal right posterior plate; Ssp, sulcal left posterior plate; Sp, sulcal posterior plate; $1^{\prime \prime \prime}$ up to $5^{\prime \prime \prime}$, postcingular plates; $1^{\prime \prime \prime \prime}$ and $2^{\prime \prime \prime \prime}$, antapical plates. (A) Ventral view (strain SZN28). (B) Ventral view of a slightly expanded cell (strain A8/1). (C) Apical pore (strain $\mathrm{A} 8 / 1$ ), the foramen $(\mathrm{F})$ is shown by an arrow: black arrows indicate marginal pores. (D) Sulcal area (strain A8/1). (E) Sulcal area of a slightly expanded cell (strain A8/1). (F) Dorsal view (strain A8/1). (G) Antapical view (strain A8/1). Scale bars: A, B, D$\mathrm{G}, 5 \mu \mathrm{m} ; \mathrm{C}, 1 \mu \mathrm{m}$.

two very small projections of the sulcal lists are visible at the antapical margin of the hypotheca. Cells appear smooth in LM (Fig. 1). Small scattered pores are visible

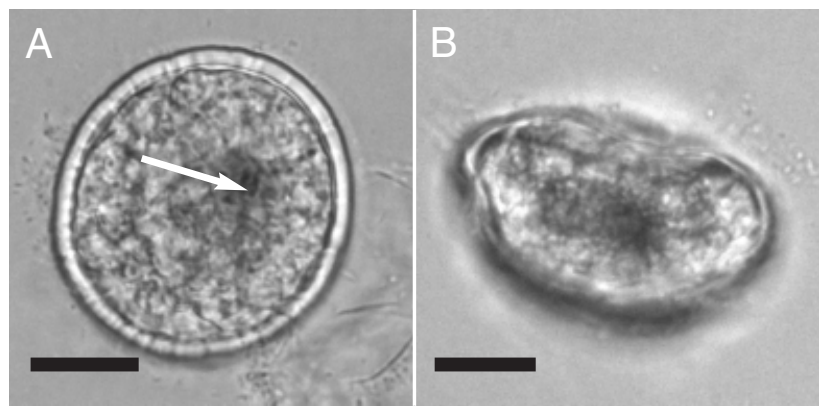

Fig. 4. Alexandrium tamutum sp. nov., light micrographs of resting cysts. (A) Round cyst seen from above; the accumulation body is shown by an arrow. (B) Kidney-shaped outline of a cyst in lateral view. Scale bars, $10 \mu \mathrm{m}$. on the thecal plates when cells are observed at SEM (Fig. 3). Cells have numerous brownish chloroplasts and a horseshoe-shaped nucleus located in the equatorial portion of the cell (Fig. 1A).

The plate formula is Po, $4^{\prime}, 0 \mathrm{a}, 6^{\prime \prime}, 6 \mathrm{C}, 9 \mathrm{~S}, 5^{\prime \prime \prime}, 2^{\prime \prime \prime \prime}$ (Fig. 2). The pore plate (Po) is slightly convex on its left margin and straight on its right margin (Fig. 3C). The canopy is narrow; the foramen (or comma) is bordered by well-developed margins. Marginal pores are present on the pore plate (Fig. 3C). The ventral end of $\mathrm{Po}$ is truncated and in contact with plate $1^{\prime}$ (Fig. 3, A-C). Plate $1^{\prime}$ has the typical rhomboidal shape with truncated anterior and posterior angles and two longer (anterior right, posterior left) and two shorter sides (Figs. 1B, 2A, and 3, A and B). The posterior margin of this plate contacts the anterior sulcal plate $(\mathrm{Sa})$. A small ventral pore is located on the anterior half of the anterior right margin of plate $1^{\prime}$ (Figs. 1B, 2A, and 3, A and $\mathrm{B})$. Plate $6^{\prime \prime}$ is wide, with a width:length ratio $\cong 1$ 
TABle 2. Dimensions of Alexandrium tamutum sp. nov. strains.

\begin{tabular}{lcccccc}
\hline \hline Strains & Length $^{\mathrm{a}}(\mu \mathrm{m})$ & Minimum length & Maximum length & Width $^{\mathrm{a}}(\mu \mathrm{m})$ & Minimum width & Maximum width \\
\hline A8/1 & $26.0(3.4)$ & 21.5 & 31.4 & $25.0(2.7)$ & 20.9 & 30.2 \\
AT5 & $26.3(3.3)$ & 22.1 & 33.1 & $25.2(3.1)$ & 19.8 \\
AT3 & $26.4(2.6)$ & 22.1 & 33.7 & $25.7(2.3)$ & 21.5 & 32.6 \\
SZN28 & $28.0(2.7)$ & 19.0 & 34.0 & $27.5(2.7)$ & 19.0 & 32.6 \\
SZN29 & $27.3(2.9)$ & 20.5 & 32.0 & $26.6(3.4)$ & 20.0 & 32.0 \\
\hline
\end{tabular}

For each strain, 30 exponentially growing cells were measured.

${ }^{\mathrm{a}}$ Values in parentheses are SD.

(Figs. 1B, 2B, and 3, A and B). Cingular plates are similar in size and are ornamented by very small poroids along their anterior and posterior margins. The sulcus is composed of nine sulcal plates (Figs. 2C and $3, \mathrm{D}$ and $\mathrm{E}$ ). The anterior sulcal plate (Sa) is as long as wide, with a straight anterior margin that contacts the posterior side of plate $1^{\prime}$. The left margin of $\mathrm{Sa}$ is straight and in contact with plate $1 \mathrm{C}$. The right margin is oblique and in contact with $6^{\prime \prime}$. The left anterior sulcal plate (Ssa) is narrow and almost rectangular. The right anterior sulcal plate (Sda) is trapezoidal in shape and bears a small list on its left side, toward the ventral part of the cell. The anterior sulcal median plate (Sma) is small, almost ellipsoidal, and is located underneath the $\mathrm{Sa}$; the posterior sulcal median plate (Smp) is slightly longer that wide. One very small arrowhead-shaped sulcal accessory platelet (Sac) is located at the posterior left end of the Sa plate and is completely hidden by the list of the Sda. The right and left posterior sulcal plates (Sdp and Ssp) are similar in shape and longer than wide. The posterior sulcal plate $(\mathrm{Sp})$ is roughly rectangular, wider than longer (Figs. 2C and 3, E and $\mathrm{G})$. The anterior margin of plate $\mathrm{Sp}$ is subdivided into two parts, which represent the borders with the left and right posterior sulcal plates. In the hypotheca, plate $1^{\prime \prime \prime \prime}$ bears a thin list along its right side in contact with the sulcal area (Fig. 3, A, B, D, and E). Plate $2^{\prime \prime \prime \prime}$ is pentagonal and large (Fig. 3G).

Resting cysts were obtained only by crossing cultures SZN29 and SZN28, both isolated from the Gulf of Naples. Cysts of $A$. tamutum have an average diameter of $29.8 \mu \mathrm{m}$ ( $n=30$; minimum diameter, $26 \mu \mathrm{m}$; $\max$ imum diameter, $32 \mu \mathrm{m})$. They are almost hemispherical in shape, with a circular outline when observed from above (Fig. 4A) and kidney shaped (Fig. 4B) in lateral view (16-20 $\mu \mathrm{m}$ high). Cysts contain granular material and an orange accumulation body (Fig. 4A). The cyst wall is thick and surrounded by a layer of mucous material by which they stick to the bottom of the culture plate.

In the Gulf of Naples, A. tamutum and A. minutum strains were isolated from the long-term sampling station MareChiara located 1 mile offshore. The strains used in the present investigation were isolated in May, when the seasonal thermocline was located at $15 \mathrm{~m}$, surface water temperature was around $24^{\circ} \mathrm{C}$, and salinity was $37.5 \mathrm{psu}$. Both species were found in net samples, whereas they were absent from the seawater samples settled for quantitative analyses. The $A$. minutum strain presented the typical features described for the species. Cells were small (18-25 $\mu \mathrm{m}$ in length), with a smooth thecal plate, a very narrow $6^{\prime}$ (precingular plate), and a rhomboidal 1' with the ventral pore located on the posterior side of the right anterior margin (Fig. 5). In the Gulf of Trieste, the two species were isolated in January and March, with temperatures ranging between 9.9 and $10.6^{\circ} \mathrm{C}$ and salinity between 37.2 and 37.5 psu.

Toxin analyses. All strains of A. tamutum tested for PSP toxins with HPLC analyses showed no toxin content. Strain SZN30 (A. minutum) showed the presence of the following PSP toxins: neosaxitoxin $\left(2.45 \mathrm{fg} \cdot\right.$ cell $\left.^{-1}\right)$, GTX1 $\left(193 \mathrm{fg} \cdot\right.$ cell $\left.^{-1}\right)$, GTX2 $\left(10.7 \mathrm{fg} \cdot\right.$ cell $\left.^{-1}\right)$, GTX3 $\left(4.73 \mathrm{fg} \cdot \mathrm{cell}^{-1}\right)$, and GTX4 $\left(171 \mathrm{fg} \cdot\right.$ cell $\left.^{-1}\right)$.

Phylogenetic analysis. The SSU rDNA phylogeny shows that the genus Alexandrium is monophyletic (Fig. 6). Within Alexandrium, A. taylori diverged first, followed by $A$. margalefi. Thereafter, the remaining taxa diverged in two major clades. The first clade, supported with moderate to strong bootstrap values, includes $A$. minutum, A. ostenfeldii, and A. tamutum. The new species $A$. tamutum is a sister taxon to $A$. ostenfeldii, and both are sisters to $A$. minutum strains. The second major cluster contains $A$. affine, followed by the later divergence of $A$. tamiyavanichi and then
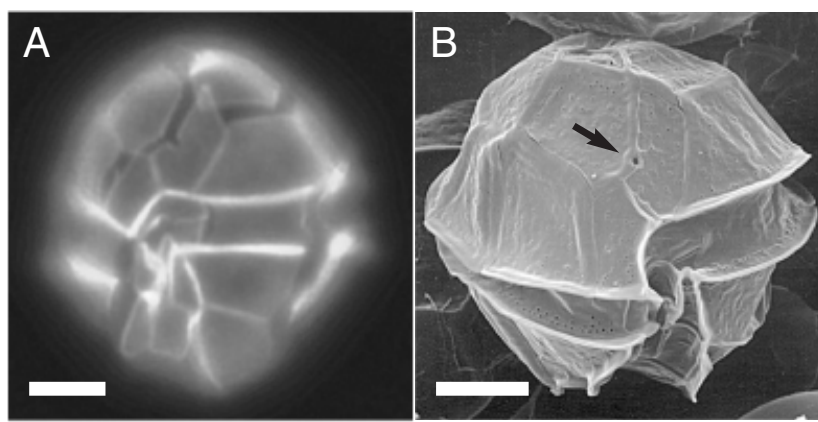

FIG. 5. Alexandrium minutum, vegetative cells of strain SZN30. (A) Light micrograph of a vegetative cell. (B) SEM micrograph of a vegetative cell in ventral/apical view; the ventral pore is shown by an arrow. Scale bars, $5 \mu \mathrm{m}$ 


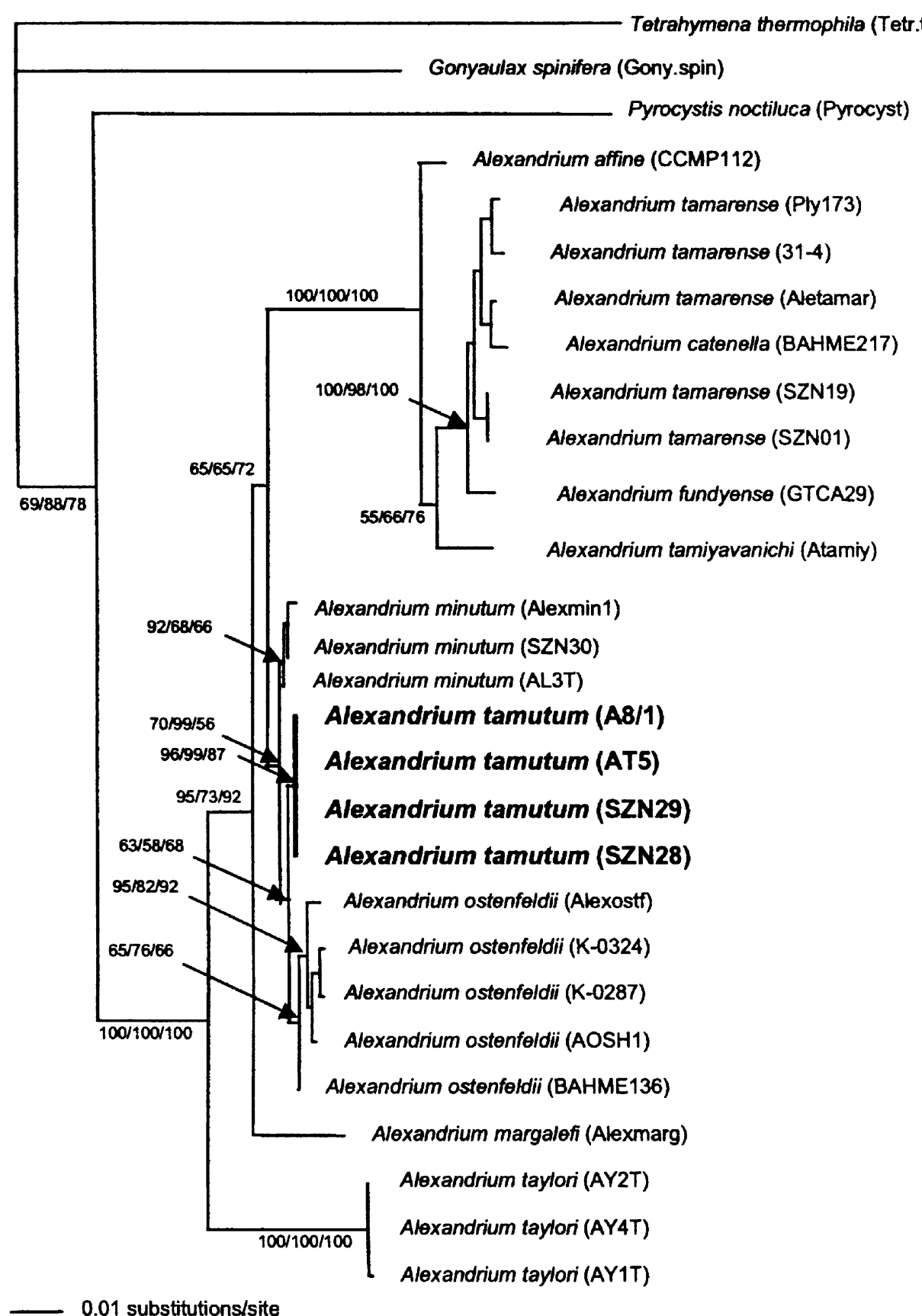

FIG. 6. ML phylogenetic tree of SSU rDNA sequences of the genus Alexandrium. Tetrahymena thermophila, Gonyaulax spinifera, and Pyrocystis noctiluca were used as outgroups. MP/NJ/ML bootstrap values $(>50 \%)$ are placed close to each node or to an arrow directing toward a node. The MP tree had a length of 1074 steps, a 0.7933 consistency index, and 0.8323 retention index.

0.01 substitutions/site

the A.tamarense "species complex" sensu Scholin et al. (1995).

The phylogenetic tree inferred from the D1/D2 region of the LSU rDNA (Fig. 7) differed from the SSU tree in the following aspects. The ML tree shows three lineages, the first one, comprising $A$. taylori and $A$. margalefi, diverging before two major sister lineages, which have a similar topology to the SSU tree but include more species. The first of the sister lineages shows the previously known topology of a first divergence of $A$. affine and $A$. concavum, followed by $A$. tamiyavanichi and then the $A$. tamarense species complex. The A. tamarense species complex reflects the different geographic clades and not the three morphotypes (A. fundyense, A. catenella, A. tamarense) known to occur in this species complex. The second of the sister lineages consists of $A$. andersoni, diverging before the lineage splits again into two clades. One of these two clades includes $A$. minutum/lusitanicum and the other includes $A$. tamutum and $A$. ostenfeldii. Most clades of the SSU tree and most of those in the LSU tree showed moderate to good bootstrap support for the branching order of the younger major lineages. In both trees the shallower clades, corresponding to 


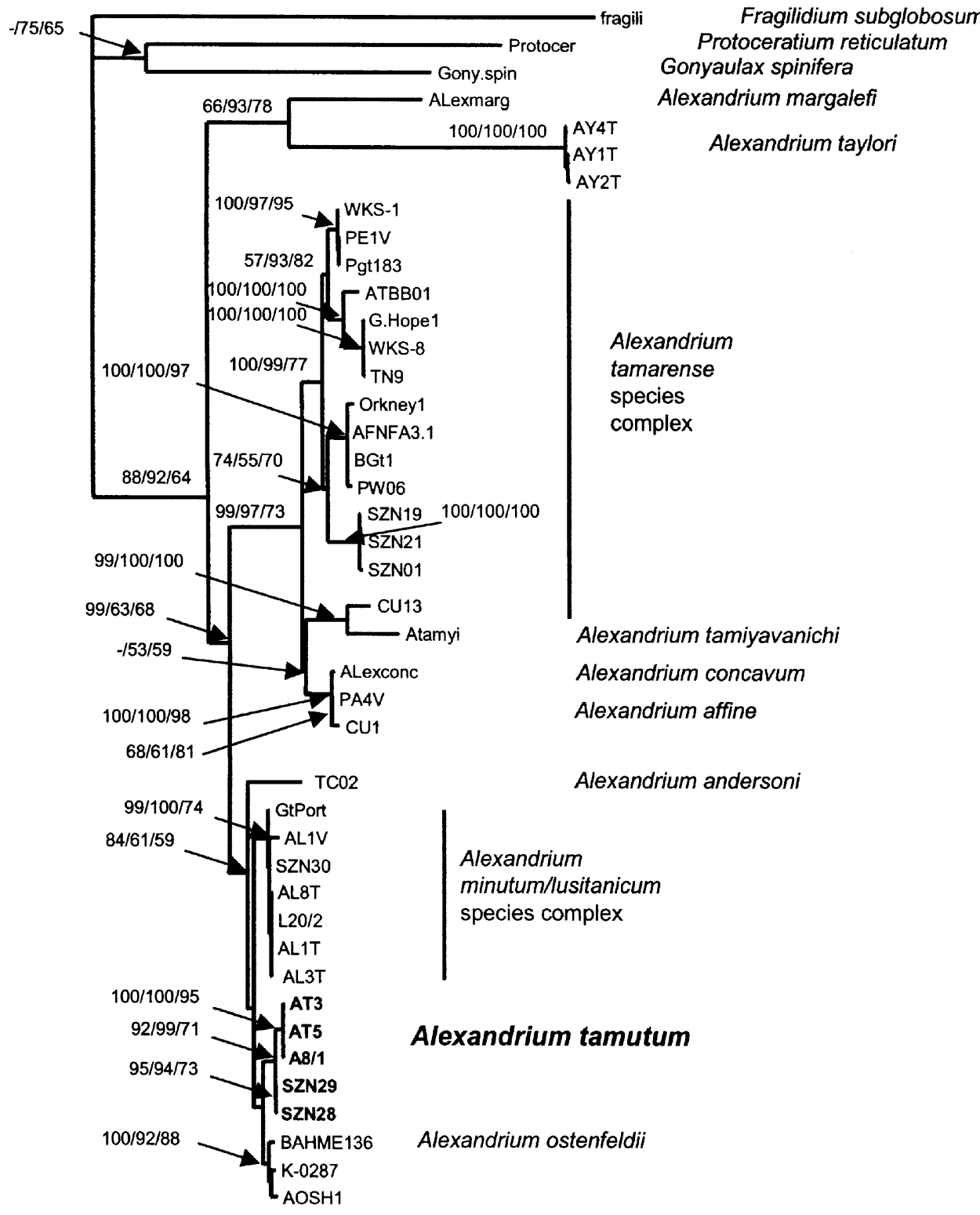

FIG. 7. ML phylogenetic tree of representatives of the genus Alexandrium based on their sequences of the D1/D2 region of the LSU rDNA. Fragilidium subglobosum, Protoceratium reticulatum, and Gonyaulax spinifera were used as outgroups. $\mathrm{MP} / \mathrm{NJ} / \mathrm{ML}$ bootstrap values $(>50 \%)$ are placed close to each node or an arrow directing toward a node. The MP tree had a length of 1382 steps, a 0.6143 consistency index, and 0.8071 retention index

0.1 substitutions/site

species groups or species complexes (see above), were well supported by bootstrap values. However, the low bootstrap support for the nodes of the A. minutum/ lusitanicum, A. tamutum, and A. ostenfeldii clade in the phylogenetic tree of the D1/D2 region did not resolve relationships among the three species.

\section{DISCUSSION}

Results of morphological investigations reveal that A. tamutum is a new species. Although it shares several morphological characters with A. minutum (e.g. small size, shape of the sulcal posterior plate, cyst morphology), it is distinguishable from the latter species by the larger size and width of its sixth precingular plate $\left(6^{\prime \prime}\right)$.
Moreover, results of HPLC analyses for PSP toxin detection showed that $A$. tamutum strains do not produce PSP toxins, whereas $A$. minutum generally does (Hallegraeff et al. 1988, Oshima et al. 1989, Franco et al. 1994, Chang et al. 1997, this investigation). Results of phylogenetic inferences on the SSU and partial LSU of the nuclear rDNA support the recognition of $A$. tamutum as a distinct species. Strains isolated from coastal waters in two Mediterranean sites (Gulf of Naples, Tyrrhenian Sea and Gulf of Trieste, Adriatic Sea) clustered together with high bootstrap values and were not intermingled with isolates of A. minutum from different geographic areas.

Morphology. Species of the genus Alexandrium share a plate pattern of Po, 4',0a, 6", 6c, 9-10 s, $5^{\prime \prime}$, 
ALEXANDRIUM TAMUTUM SP. NOV.

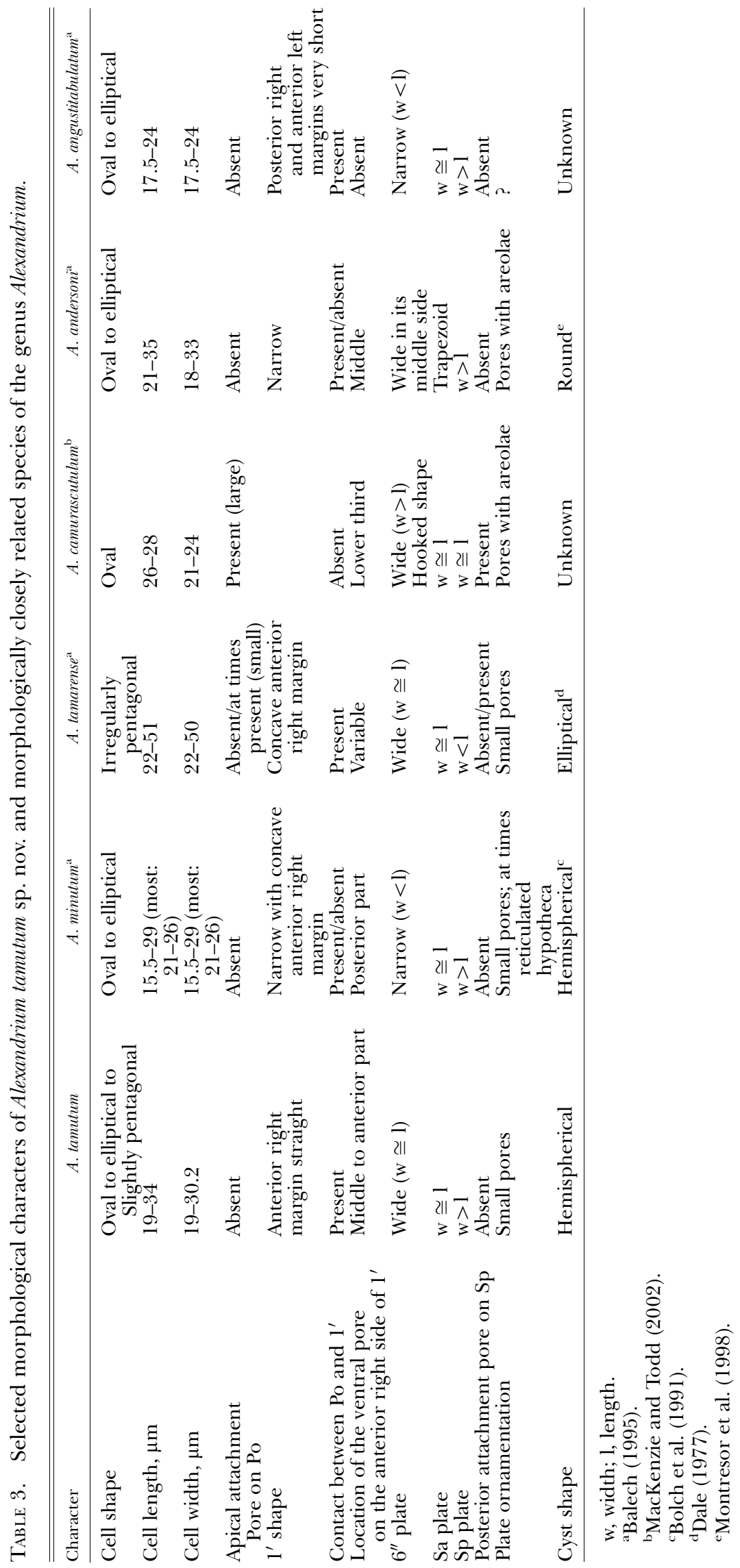




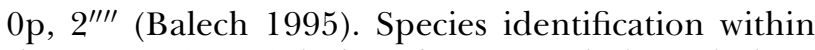
this genus is mainly based on morphological characters, such as cell shape, size, chain formation, presence or absence of a ventral pore, and shape and size of some specific thecal plates, namely, first apical, pore plate, sixth precingular, anterior and posterior sulcal plates. Most of these characters are visible only upon dissecting thecal plates under the microscope, staining them with fluorochromes (Fritz and Triemer 1985), or after the examination of cells at SEM. The painstaking study in LM of hundreds of samples from all over the world allowed Balech (1995) to set a comprehensive classification framework for Alexandrium species, based on the combination of several morphological characters of the vegetative cells. The genus presently includes 28 species plus a number of species/morphotypes, which still need to be investigated to assess definitively their taxonomic status (Balech 1995, MacKenzie and Todd 2002).

Strains of $A$. tamutum present morphological characters, which are shared at times by $A$. minutum and at times by $A$. tamarense (Table 3 ). The cell outline of A. tamutum is generally rounded or elliptical. This, together with its relatively small size, at first sight is reminiscent of $A$. minutum, to one of the small-sized species included in the "A. minutum group," or to the recently described $A$. camurascutulum (Table 3) (Balech 1995, MacKenzie and Todd 2002). However, A. tamutum cells in their larger size range present a slightly pentagonal shape, thus reflecting the outline of small-sized $A$. tamarense. The above-mentioned species have distinct size ranges, but they overlap widely; thus, cell size is not a useful character for distinguishing Alexandrium species.

The large size of plate $6^{\prime \prime}$ in the precingular series, with a width:height ratio $\approx 1$, differs from that described for $A$. minutum and is most similar to the $6^{\prime \prime}$ plate described for $A$. tamarense (Table 3). This is the main morphological character that distinguishes our new species from $A$. minutum. A distinctive morphological feature of this latter species is in fact the very narrow shape and reduced size of the sixth precingular plate (Balech 1989, 1995). The sulcal posterior plate (Sp) of A. tamutum is of the "minutum type," viz. roughly rectangular in shape and wider than high, whereas the Sp of A. tamarense is distinctively higher than wide (Balech 1995). The small-sized A. camurascutulum also presents a wide 6" plate, which, however, is wider than long and has a characteristic hooked shape because of the strongly curved left anterior margin (MacKenzie and Todd 2002). Moreover, this latter species can be distinguished from $A$. tamutum and the other species included in the minutum group by a longer sulcal posterior $(\mathrm{Sp})$ plate and by the presence of a large attachment pore on both the sulcal posterior plate and the pore plate (Table 3 ).

The pore plate of $A$. tamutum resembles that of A. minutum, with an almost undetectable callus and small marginal pores surrounding the foramen (or comma). Plate $1^{\prime}$ has a small ventral pore on its anterior right side. However, whereas in A. minutum the ventral pore is located on the posterior end of the anterior right margin of plate $1^{\prime}$ (Balech 1995), in A. tamutum the pore is situated in the median/upper part of the margin. In all the strains of A. tamutum examined, the connection between the pore plate and plate $1^{\prime}$ is clearly visible, whereas in $A$. minutum this connection is at times hidden by the overgrowth of the margins of plates $2^{\prime}$ and $4^{\prime}$.

The hypothecal plates of $A$. tamutum are smooth, whereas those of $A$. minutum in the type locality (Balech 1989 ) and the two strains of $A$. minutum we examined here also had a smooth hypotheca. Specimens attributed to A. minutum with evident hypothecal ornamentation have been reported for natural material collected in the Gulf of Naples and Japanese waters (Montresor et al. 1990, Yuki 1994, Balech 1995). It is not known if the microreticulation is a stable character or if it can be lost in culture conditions, and no molecular data relative to a reticulated morphotype of A. minutum are available to our knowledge. Montresor et al. (1990), reporting on Alexandrium species from the Gulf of Naples, illustrated a cell of A. minutum characterized by a narrow 6" plate and a strongly reticulated hypotheca (their fig. 3b). However, they also illustrated a cell (their fig. 3a) that instead had a wide sixth precingular plate and should probably be attributed to A. tamutum.

The cyst. The resting cysts of A. tamutum are morphologically identical to those of $A$. minutum (Bolch et al. 1991). Almost all Alexandrium cysts known up to now are ellipsoidal (A. tamarense, A. catenella, A. cohorticula), spherical (A. affine, A. leei, A. monilatum, A. ostenfeldii, A. taylori), or approximately hemispherical (A. minutum, A. lusitanicum, $A$. hiranoi) in shape, with a smooth wall surrounded by a more or less developed mucous layer and deprived of any morphological feature that could help for their identification at the species level (Bolch et al. 1991, MacKenzie et al. 1996, Garcés et al. 1998). The only exception to the smooth-walled cysts is represented by the cyst of $A$. pseudogonyaulax, which presents clear markings reflecting the tabulation of the vegetative cell (Montresor et al. 1993, Montresor 1995).

The presence of a heterothallic life cycle has been reported for A. catenella (Yoshimatsu 1981), whereas for $A$. tamarense a more complex probably multiple mating type system has been suggested (Destombe and Cembella 1990). In A.tamutum, resting cysts were never observed within cultures established from the isolation of a single cell but only after crossing strains of different mating type. Interestingly, cyst formation was only obtained by crossing strains from the Gulf of Naples, whereas no cysts were observed in crossings among the isolates from the Gulf of Trieste or among them and the Neapolitan strains. Cyst formation can be interpreted as evidence for sexual reproduction and thus mating compatibility between two strains, but the lack of cyst formation cannot be considered as evidence for lack of 
sexual reproduction. Several possible factors could explain the lack for cyst formation. The strains of A. tamutum isolated from the Adriatic Sea could have belonged to the same mating type, and thus the crossing among them should have been ineffective. However, if $A$. tamutum has a simple heterothallic life cycle with mating types of two opposite signs, the Adriatic strains should have been compatible with one of the two Neapolitan strains. An alternative hypothesis is the presence of multiple mating types in A. tamutum as in A. tamarense and Gymnodinium catenatum Graham (Destombe and Cembella 1990, Blackburn et al. 2001). We can also hypothesize that mating barriers start to establish between strains from the Gulf of Trieste and those from the Gulf of Naples as suggested by the separation of the two strains in the phylogenetic tree based on LSU sequences. Ultimately, sexual reproduction (i.e. conjugation and zygote formation) could have occurred but without leading to encystment, perhaps because the required conditions were not met in the experimental condition we used.

Toxicity. HPLC analyses showed that A. tamutum strains from both the Gulfs of Naples and Trieste do not produce PSP toxins, whereas the two strains of A. minutum are toxic (Tillmann and John 2002, this investigation). The first HPLC analyses carried out on A. minutum detected the presence of GTX $1,2,3$, and 4 (Oshima et al. 1989). However, notable variability in toxin content and relative proportions has been observed in strains from different geographic areas or in different culture conditions (Franco et al. 1994, Béchemin et al. 1999, Hwang and Lu 2000), and isolates from New Zealand showed neosaxitoxin as the principal component (Chang et al. 1997). Small amounts of this toxin were also detected in the Neapolitan strain of $A$. minutum, whereas it was not detected in the strain isolated from the Gulf of Trieste (Tillmann and John 2002). It is interesting to note that another strain of A. minutum (AL1 T), isolated from the Gulf of Trieste and included in the present LSU phylogeny, was not found to produce PSP toxins (Tillmann and John 2002). This is, to our knowledge, the first report of a non-PSP-producing A. minutum.

Phylogenetic relationships within the genus Alexandrium. Phylogenetic analyses carried out on the SSU and LSU of the nuclear rDNA of multiple strains of different Alexandrium species showed that the addition of strains of the new species A. tamutum does not change the basic topology of trees obtained in previous investigations (John et al. 2003b). Alexandrium taylori and A. margalefi are at the base of the Alexandrium clade, which then splits into two major clades: one grouping species of the $A$. tamarense species complex, A. tamiyavanichi and A. affine, and the other including $A$. minutum, A. tamutum, and $A$. ostenfeldii. Molecular phylogenies failed to support supraspecific groupings suggested for the genus Alexandrium (Balech 1995) and do not help us in understanding which of the morphological characters we currently use for morphological investigations have to be considered ancestral or derived.

In the taxonomic revision of the genus Alexandrium, Balech (1995) grouped some of the species sharing peculiar morphological features within supraspecific "groups." One of them is the minutum group (A. andersoni, A. angustitabulatum, A. minutum, and A. lusitanicum) that includes species generally less than $30 \mu \mathrm{m}$ in size, with a short, wider than long, posterior sulcal plate $(\mathrm{Sp})$ and a very narrow sixth precingular plate $\left(6^{\prime \prime}\right)$. Our molecular analyses, which include all but one (A. angustitabulatum) species of the minutum group, showed no phylogenetic support for this supraspecific clustering. Strains of $A$. minutum and $A$. lusitanicum group together in a well-supported clade, confirming that they should be considered the same species, as already hypothesized by Balech and suggested by other authors (Balech 1995, Costas et al. 1995, Franco et al. 1995). However, A. andersoni does show close phylogenetic relationship with $A$. minutum, branching out at the base of the $A$. minutum-A. tamutum-A. ostenfeldii clade.

Phylogenetic studies within the genus Alexandrium have been mainly focused on the so-called $A$. tamarense species complex, which groups three morphospecies, A. tamarense, $A$. fundyense, and $A$. catenella, responsible of harmful events worldwide. These three species are distinguished based on the combination of two main characters: presence (A. tamarense) or absence $(A$. fundyense, $A$. catenella) of a ventral pore on the first apical plate and formation (A. catenella) or lack of formation (A.tamarense, $A$. fundyense) of long chains of cells (Balech 1995). However, molecular analyses carried out on the variable domains of the LSU rDNA of a large number of strains from different geographic areas showed that the different morphospecies clustered together based on their biogeographic origin and not on their morphological features (Scholin et al. 1994, 1995, Medlin et al. 1998, Higman et al. 2001, John et al. 2003b). This pattern has been explained with the evolution of genetically distinct populations via geographic isolation coupled by human-mediated dispersal (Scholin et al. 1995). A paleobiogeographic scenario based on the calculation of a possible molecular clock has been recently proposed to integrate this hypothesis (John et al. 2003b). The high level of genetic diversity detected within the $A$. tamarense complex compared with that recorded among strains of other morphospecies (e.g. A. minutum, A. tamutum, and $A$. ostenfeldii) from different geographic areas further supports the presence of cryptic species within the A. tamarense complex, as shown for other dinoflagellate species (Montresor et al. 2003). Unfortunately, no comparably extensive data sets are available for other Alexandrium species, and the assessment of the level of genetic diversity within other morphospecies, as well as the phylogenetic relationships among the different species, are still far from being complete. Until now, the different phylogenies obtained for this genus failed to provide a match with the morphological 
characters currently used for species identification. Multiple strains of species that have been identified based on morphological features of their thecal plates indeed group in the same clade. However, for none of these characters (e.g. presence/absence of ventral pore, shape of $1^{\prime}$ or $6^{\prime \prime}$ plates, cyst morphology) is it possible to trace a state that is consistent with the evolutionary picture obtained from molecular analyses. Recently, the grouping of Alexandrium species based on the shape of the sulcal posterior plate has been suggested by Usup et al. (2002), but no support for this classification emerged from our data.

Alexandrium tamutum and A. minutum are so extremely similar in size and cell outline that they cannot be distinguished during routine cell counts in LM. Both in the Gulfs of Naples and Trieste the two species were detected and identified during investigations carried out on net samples. In the Gulf of Naples, A. andersoni, which is another small-sized species, almost indistinguishable from the two mentioned above, has been found (Montresor et al. 1998). Considering that two of the species, $A$. andersoni and $A$. minutum, are PSP producers (Ciminiello et al. 2000, this investigation), their precise identification in monitoring programs becomes a rather important issue. Molecular probes thus represent an extremely promising tool for the rapid and certain $\mathrm{HAB}$ species identification (John et al. 2003a). Our results show that the three species are genetically distinct, and the branch lengths leading to this clade would suggest that species-specific rRNA probes based either on SSU or LSU rDNA sequences could be developed for qualitative and quantitative identification.

We thank Dr. Roberto Poletti (Centro Ricerche Marine, Cesenatico, Italy), Dr. Sergio Predonzani, and Dr. Stefano Piselli (Laboratorio di Biologia Marina, Trieste, Italy) for toxicity analyses and Prof. Marta Maria Giannone for translating the species diagnosis into Latin. M. M. thanks Carmen Minucci for culture maintenance and Gandi Forlani for technical assistance in SEM preparations.

Adachi, M., Sako, Y. \& Ishida, Y. 1994. Restriction fragment length polymorphism of ribosomal DNA internal transcribed spacer and 5.8S regions in Japanese Alexandrium species (Dinophyceae). J. Phycol. 30:857-63.

Adachi, M., Sako, Y. \& Ishida, Y. 1996a. Analysis of Alexandrium (Dinophyceae) species using sequences of the $5.8 \mathrm{~S}$ ribosomal DNA and internal transcribed spacer regions. J. Phycol. $32: 424-32$.

Adachi, M., Sako, Y. \& Ishida, Y. 1996b. Identification of the toxic dinoflagellates Alexandrium catenella and A. tamarense (Dinophyceae) using DNA probes and whole-cell hybridization. J. Phycol. 32:1049-52.

Anderson, D. M., Kulis, D. M., Doucette, G. J., Gallagher, J. C. \& Balech, E. 1994. Biogeography of toxic dinoflagellates in the genus Alexandrium from the northeastern United States and Canada. Mar. Biol. 120:467-78.

Anderson, D. M., Kulis, D. M., Keafer, B. A. \& Berdalet, E. 1999. Detection of the toxic dinoflagellate Alexandrium fundyense (Dinophyceae) with oligonucleotide and antibody probes: variability in labeling intensity with physiological conditions. J. Phycol. 35:870-83.
Balech, E. 1989. Redescription of Alexandrium minutum Halim (Dinophyceae) type species of the genus Alexandrium. Phycologia 28:206-11.

Balech, E. 1995. The Genus Alexandrium halim (Dinoflagellata). Sherkin Island Marine Station, Sherkin Island, Co. Cork, Ireland, $151 \mathrm{pp}$.

Béchemin, C., Grzebyk, D., Hachame, F., Hummert, C. \& Maestrini, S. Y. 1999. Effect of different nitrogen/phosphorus nutrient ratios on the toxin content in Alexandrium minutum. Aquat. Microb. Ecol. 20:157-65.

Blackburn, S. I., Bolch, C. J. S., Haskard, K. A. \& Hallegraeff, G. M. 2001. Reproductive compatibility among four global populations of the toxic dinoflagellate Gymnodinium catenatum (Dinophyceae). Phycologia 40:78-87.

Bolch, C. J., Blackburn, S. I., Cannon, J. A. \& Hallegraeff, G. M. 1991. The resting cyst of the red-tide dinoflagellate Alexandrium minutum (Dinophyceae). Phycologia 30:215-9.

Chang, F. H., Anderson, D. M., Kulis, D. M. \& Till, D. G. 1997. Toxin production of Alexandrium minutum (Dinophyceae) from the Bay of Plenty, New Zealand. Toxicon 35:393-409.

Ciminiello, P., Fattorusso, E., Fiorino, M. \& Montresor, M. 2000. Saxitoxin and neosaxitoxin as toxic principles of Alexandrium andersoni (Dinophyceae) from the Gulf of Naples, Italy. Toxicon 38:1871-7.

Codd, G. A., Bell, S. G., Kaya, K., Ward, C. J., Beattle, K. A. \& Metcalf, J. S. 1999. Cyanobacterial toxins, exposure routes and human health. Eur. J. Phycol. 34:405-15.

Costas, E., Zardoya, R., Bautista, J., Garrido, A., Rojo, C. \& LopezRodas, V. 1995. Morphospecies vs. genospecies in toxic marine dinoflagellates: an analysis of Gymnodinium catenatum, Gyrodinium impudicum and Alexandrium minutum, A. lusitanicum using antibodies, lectins and gene sequences. J. Phycol. 31:801-7.

Dale, B. 1977. Cysts of the toxic red-tide dinoflagellate Gonyaulax excavata (Braarud) Balech from Oslofjorden, Norway. Sarsia 63:29-34.

Delgado, M., Estrada, M., Camp, J., Fernandez, J. V., Santmarti, M. \& Lleti, C. 1990. Development of a toxic Alexandrium minutum Halim (Dinophyceae) bloom in the harbour of Sant Carle de la Ràpita (Ebro Delta, northwestern Mediterranean). Sci. Mar. 54:1-7.

Destombe, C. \& Cembella, A. 1990. Mating-type determination, gametic recognition and reproductive success in Alexandrium excavatum (Gonyaulacales, Dinophyta), a toxic red-tide dinoflagellate. Phycologia 29:316-25.

Doyle, J. J. \& Doyle, J. L. 1990. Isolation of plant DNA from fresh tissue. Focus 12:13-5.

Elwood, H. J., Olson, G. J. \& Sogin, M. L. 1985. The small-subunit ribosomal RNA gene sequences from the hypotrichous ciliates Oxytricha nova and Stylonychia pustalata. Mol. Biol. Evol. 2:399410.

Eppley, R. W., Holmes, R. W. \& Strickland, J. D. H. 1967. Sinking rates of marine phytoplankton measured with a fluorometer. J. Exp. Mar. Biol. Ecol. 1:191-208.

Felsenstein, J. 1985. Confidence limits on phylogenies: an approach using the bootstrap. Evolution 39:783-91.

Franco, J. M., Fernandez, P. \& Reguera, B. 1994. Toxin profiles of natural populations and cultures of Alexandrium minutum Halim from Galician (Spain) coastal waters. J. Appl. Phycol. 6:275-9.

Franco, J. M., Fraga, S., Zapata, M., Bravo, I., Fernàndez, P. \& Ramilo, I. 1995. Comparison between different strains of genus Alexandrium of the minutum group. In Lassus, P., Arzul, G., Erard, E., Gentien, P. \& Marcaillou, C. [Eds.] Harmful Marine Algal Blooms. Lavoisier, Intercept Ltd., Paris, pp. $53-8$.

Fritz, L. \& Triemer, R. E. 1985. A rapid simple technique utilizing Calcofluor White M2R for the visualization of dinoflagellate thecal plates. J. Phycol. 21:662-4.

Garcés, E., Delgado, M., Masó, M. \& Camp, J. 1998. Life history and in situ growth rates of Alexandrium taylori (Dinophyceae, Pyrrhophyta). J. Phycol. 34:880-7.

Halim, Y. 1960. Alexandrium minutum nov. g. nov. sp. dinoflagellé provocant des 'eaux rouges'. Vie Milieu 11:102-5. 
Hallegraeff, G. M., Steffensen, D. A. \& Wetherbee, R. 1988. Three estuarine Australian dinoflagellates that can produce paralytic shellfish toxins. J. Plankton Res. 10:533-41.

Higman, W. A., Stone, D. M. \& Lewis, J. M. 2001. Sequence comparison of toxic and non-toxic Alexandrium tamarense (Dinophyceae) isolates from UK waters. Phycologia 40:256-62.

Hoagland, K. D., Anderson, D. M., Kaoru, Y. \& White, A. W. 2002. The economic effects on harmful algal blooms in the United States: estimates, assessment issues, and information needs. Estuaries 25:819-37.

Hwang, D. F. \& Lu, Y. H. 2000. Influence of environmental and nutritional factors on growth, toxicity, and toxin profile of dinoflagellate Alexandrium minutum. Toxicon 38:1491-503.

John, U., Cembella, A., Hummert, C., Elbrächter, M., Groben, R. \& Medlin, L. 2003a. Discrimination of the toxigenic dinoflagellates Alexandrium tamarense and $A$. ostenfeldii in co-occurring natural populations from Scottish coastal waters. Eur. J. Phycol. $38: 25-40$.

John, U., Fensome, R. A. \& Medlin, L. K. 2003b. The application of a molecular clock based on molecular sequences and the fossil record to explain biogeographic distributions within the Alexandrium tamarense "species complex" (Dinophyceae). J. Mol. Evol. 20:1015-27.

Keller, M. D., Selvin, R. C., Claus, W. \& Guillard, R. R. L. 1987. Media for the culture of oceanic ultraphytoplankton. J. Phycol. 23:633-8.

Lilly, E. L., Kulis, D. M., Gentien, P. \& Anderson, D. M. 2002. Paralytic shellfish poisoning toxins in France linked to a human-introduced strain of Alexandrium catenella from the western Pacific: evidence from DNA and toxin analysis. J. Plankton Res. 24:443-52.

MacKenzie, L. \& Todd, K. 2002. Alexandrium camurascutulum sp. nov. (Dinophyceae): a new dinoflagellate species from New Zealand. Harmful Algae 1:295-300.

MacKenzie, L., White, D., Oshima, Y. \& Kapa, J. 1996. The resting cyst and toxicity of Alexandrium ostenfeldii (Dinophyceae) in New Zealand. Phycologia 35:148-55.

Margalef, R. \& Estrada, M. 1987. Synoptic distribution of summer microplancton (Algae and Protozoa) across the principal front in the western Mediterranean. Invest. Pesq. 51:121-40.

Medlin, L. K., Elwood, H. J., Stickel, S. \& Sogin, M. L. 1988. The characterization of enzymatically amplified eukaryotic 16S-like rRNA-coding regions. Gene 71:491-9.

Medlin, L. K., Lange, M., Wellbrock, U., Donner, G., Elbrächter, M., Hummert, C. \& Luckas, B. 1998. Sequence comparisons link toxic European isolates of Alexandrium tamarense from the Orkney Islands to toxic American stocks. Eur. J. Protistol. 34:329-35.

Moestrup, Ø., Codd, G. A., Elbrächter, M., Faust, M. A., Fraga, S., Fukuyo, Y., Cronberg, G., Halim, Y., Taylor, F. J. R. \& Zingone, A. 2002. IOC taxonomic reference list of toxic algae. Intergovernmental Oceanographic Commission of UNESCO, http://ioc.unesco.org/hab/data4taxlist.htm.

Montresor, M. 1995. The life history of Alexandrium pseudogonyaulax (Gonyaulacales, Dinophyceae). Phycologia 34:444-8.

Montresor, M., Marino, D., Zingone, A. \& Dafnis, G. 1990. Three Alexandrium species from coastal Tyrrhenian waters (Mediterranean Sea). In Granéli, E., Sundstrom, B., Edler, L. \& Anderson, D. M. [Eds.] Toxic Marine Phytoplankton. Elsevier, Amsterdam, pp. 82-7.

Montresor, M., Sgrosso, S., Procaccini, G. \& Kooistra, W. H. C. F. 2003. Intraspecific diversity in Scrippsiella trochoidea (Dinophyceae): evidence for cryptic species. Phycologia 42:56-70.

Montresor, M., Zingone, A. \& Marino, D. 1993. The paratabulate resting cyst of Alexandrium pseudogonyaulax (Dinophyceae). In Smayda, T. J. \& Shimizu, Y. [Eds.] Toxic Phytoplankton Blooms in the Sea. Elsevier, Amsterdam, pp. 159-64.

Montresor, M., Zingone, A. \& Sarno, D. 1998. Dinoflagellate cyst production at a coastal Mediterranean site. J. Plankton Res. 20:2291-312.

Ochoa, J. L., Sanchez-Paz, A., Cruz-Villacorta, A., Nuñez-Vazquez, E. \& Sierra-Beltran, A. 1997. Toxic events in the northwest pacific coastline of Mexico during 1992-1995: origin and impact. Hydrobiologia 352:195-200.

Oshima, Y., Hirota, M., Yasumoto, T., Hallegraeff, G. M., Blackburn, S. I. \& Steffensen, D. A. 1989. Production of paralytic shellfish toxins by the dinoflagellate Alexandrium minutum Halim from Australia. Nippon Suisan Gakkaishi 55:925.

Penna, A. \& Magnani, M. 2000. A PCR immunoassay method for the detection of Alexandrium (Dinophyceae) species. J. Phycol. 36:1183-6.

Posada, D. \& Crandall, K. A. 1998. Modeltest: testing the model of DNA substitution. Bioinform. Appl. Note 14:818.

Posada, D. \& Crandall, K. A. 2001. Selecting the best-fit model of nucleotide substitution. Syst. Biol. 50:580-601.

Scholin, C. A. \& Anderson, D. M. 1996. LSU rDNA-based RFLP assays for discriminating species and strains of Alexandrium (Dinophyceae). J. Phycol. 32:1022-35.

Scholin, C. A., Anderson, D. M. \& Sogin, M. L. 1993. Two distinct small-subunit ribosomal RNA genes in the North American toxic dinoflagellate Alexandrium fundyense (Dinophyceae). J. Phycol. 29:209-16.

Scholin, C. A., Herzog, M., Sogin, M. \& Anderson, D. M. 1994. Identification of group- and strain-specific genetic markers from globally distributed Alexandrium (Dinophyceae). II. Sequence analysis of fragments of the LSU rRNA gene. J. Phycol. 30:999-1011.

Scholin, C. A., Hallegraeff, G. M. \& Anderson, D. M. 1995. Molecular evolution of the Alexandrium tamarense species complex (Dinophyceae): dispersal in the North American and West Pacific region. Phycologia 34:472-85.

Scholin, C. A., Gulland, F., Doucette, G. J., Benson, S., Busman, M., Chavez, F. P., Cordaro, J., DeLong, R., Vogetaere, A. D., Harvey, J., Haulena, M., Lefebvre, K., Lipscomb, T., Loscutoff, S., Lowenstine, L. J., Marin, R. III, Miller, P. E., McLellan, W. A., Moeller, P. D. R., Powell, C. L., Rowles, T., Silvagni, P., Silver, M., Spraker, T., Trainer, V. \& Dolah, F. M. V. 2000. Mortality of sea lions along the central California coast linked to a toxic diatom bloom. Nature Lond. 403:80-4.

Sullivan, J. J. \& Wekell, M. M. 1984. Determination of paralytic shellfish poisoning toxins by high pressure liquid chromatography. In Ragelis, E. P. [Eds.] Seafood Toxins. American Chemical Society Symposium Series 262, Washington, DC, pp. 197-205.

Swofford, D. L. 1998. PAUP*. Phylogenetic Analysis Using Parimony (* and Other Methods). Version 4. Sinauer Associates, Sunderland, MA

Thompson, J. D., Gibson, T. J., Plewniak, F., Jeanmougin, F. \& Higgins, D. G. 1997. The Clustal X windows interface: flexible strategies for multiple sequence alignment aided by quality analysis tools. Nucleic Acids Res. 24:4876-82.

Tillmann, U. \& John, U. 2002. Toxic effects of Alexandrium spp. on heterotrophic dinoflagellates: an allelochemical defence mechanism independent of PSP-toxin content. Mar. Ecol. Prog. Ser. 230:47-58.

Usup, G., Pin, L. C., Ahmad, A. \& Teen, L. P. 2002. Phylogenetic relationship of Alexandrium tamayavanichii (Dinophyceae) to other Alexandrium species based on ribosomal RNA gene sequences. Harmful Algae 1:59-68.

Vila, M., Camp, J., Garcés, E., Masó, M. \& Delgado, M. 2001a. High resolution spatio-temporal detection of potentially harmful dinoflagellates in confined waters of the NW Mediterranean. J. Plankton Res. 23:497-514.

Vila, M., Garces, E., Maso, M. \& Camp, J. 2001b. Is the distribution of the toxic dinoflagellate Alexandrium catenella expanding along the NW Mediterranean coast? Mar. Ecol. Prog. Ser. 222:73-83.

Yoshimatsu, S. 1981. Sexual reproduction of Protogonyaulax catenella in culture. I. Heterothallism. Bull. Plankton Soc. Jpn. 28:131-9.

Yuki, K. 1994. First report of Alexandrium minutum Halim (Dinophyceae) from Japan. Jpn. J. Phycol. 42:425-30.

Zardoya, R., Costas, E., Lopez-Rodas, V., Garrido-Pertierra, A. \& Bautista, J. M. 1995. Revised dinoflagellate phylogeny inferred from molecular analysis of large subunit ribosomal RNA gene sequences. J. Mol. Evol. 41:637-45. 